\title{
An Investigation to Replace sand with Kunkur Quarry dust as fine Aggregates in Concrete.
}

\author{
Dennis Mumo Ndolo, Gwaya Abednego, Stephen Diang'a
}

\begin{abstract}
Following a national outcry by environment management organizations both governmental and non-governmental to preserve rivers it's seen to be strongly backed by political leaders which is posing a great threat to the future of construction industry. This therefore calls for thorough investigations on alternative materials which can potentially be used to replace sand either partially or fully to help preserve rivers which are the major source of sand. Sand harvesting is associated with drying up of rivers which causes water problems to the communities during the dry period. At present, the identified alternative sources are manufactured sand (mechanically crushed rock sand).This source proves to be expensive as machinery must be purchased purposely for crushing the aggregates and extra cost must be incorporated with this process. The alternative sought should therefore be of a lower cost compared to what is currently in use. The research examined the use of Kunkur fines to test its potential for use as an alternative to preserve the drying rivers. The research used quantitative design to examine its variables which extend from the raw materials, fresh and the hardened concrete. Kunkur fines from EAPCC quarry is a potential material for partially replacing sand up to $50 \%$ for fine aggregates in concrete as it qualifies the tests which are required to regard a material as having sufficient structural strength and suitable for use as fine aggregate. An increase of Kunkur fines in the blend slightly reduces the strength of concrete. Up to $50 \%$ replacement the blend gives sufficient structural strength of $20 \mathrm{~N} / \mathrm{mm}^{2}$ and above with further increase of Kunkur recording lower values than the design strength. Kunkur has low silt content which is slightly higher than that of sand by $0.91 \%$ but below the maximum required percentage by $B S 812$ of 5\%. The research recommends the use of Kunkur fines as it will help reduce the amount of sand harvested in the rivers annually by half and this will reduce the effect of water scarcity in the affected areas. Its use will also solve the problem of heap disposal by the EAPCC in the mines as the waste will be appropriately used in the construction industry.
\end{abstract}

Index Terms-Kunkur fines, Aggregates, Sand, concrete

Revised Manuscript Received on September 05, 2020.

* Correspondence Author

Mr, Dennis Mumo Ndolo, Dept. Construction Management, Jomo Kenyatta University of Agriculture \& Technology, Nairobi, Kenya, +254712554532, (dmumo@jkuat.ac.ke).

Dr. Abednego Oswald Gwaya, Dept. Construction Management, Jomo Kenyatta University of Agriculture \& Technology, Nairobi, Kenya, +254724571219, (agwaya@jkuat.ac.ke).

Prof. Stephen Onyango Diang'a, Dept. Construction Management, Jomo Kenyatta University of Agriculture \& Technology, Nairobi, Kenya, +254721790097, (sdianga@sabs.jkuat.ac.ke).

(C) The Authors. Published by Blue Eyes Intelligence Engineering and Sciences Publication (BEIESP). This is an open access article under the CC BY-NC-ND license (http://creativecommons.org/licenses/by-nc-nd/4.0/)

\section{INTRODUCTION}

Demand for buildings is increasing at a very high rate considering the fact that shelter is a basic need and a person can barely survive without. This increased demand is causing an increase in the pay for rent and investors are looking for the cheapest means possible to construct their buildings in order to lease their units with cheapest amount at high profit (Collins, 2013). Concrete forms the better part of the middle and high rise building as it is majorly used to construct the main structural elements including slabs, columns, beams and even retaining walls for basements. The concrete which contains cement, fine and coarse aggregates mixed with water should be given a greater concentration by the innovators and researchers to examine other substitutes which can replace the traditionally used materials including crushed granite stone for coarse aggregates and the river sand which has been predominantly used over the past years.

There has been an outcry by the government and other non-government environment management organizations calling for the ban of sand harvesting and this brings a greater threat to the construction industry as the firms entirely depends on this sand to produce their concrete. Construction process in the recent years has been undergoing through technological revolution where most of the work which was handled manually is being executed by machinery. In the past, execution of works was a major concern as manual construction process was very slow and the buildings used to take a very long time before completion. This led to constant researches and investigations trying to look on other alternatives which can be employed on site to accelerate the execution of works and this brought construction industry to the level of mechanization which it is today (Collins, 2013). Time crisis having been successfully solved another problem related to materials and specifically sand has emerged and the same efforts applied in solving the challenges of timely completion of projects should in fact be deviated as whole to solve the upcoming crisis of sand shortage and banning by leaders and environment preservation organizations (Collins, 2013)

\section{OBJECTIVES}

1. To investigate the possibility of replacing sand with Kunkur dust in concreting.

2. To examine the structural characteristics of the concrete made with Kunkur dust.

3. To examine the structural characteristics of the concrete made with Kunkur dust.

\section{Published By:}

Blue Eyes Intelligence Engineering

and Sci

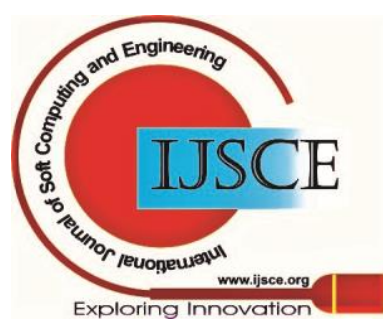




\section{An Investigation to Replace sand with Kunkur Quarry dust as fine Aggregates in Concrete.}

\section{RESEARCH METHODOLOGY}

The objective of this study is to examine the possibility of partially replacing sand with Kunkur fines for fine aggregates in concrete with a specific objective of testing its strength properties. The study achieved this by using laboratory tests to assess the strength and specific properties.

A control mix using $100 \%$ sand was made to study the behavior of the mix in question by comparing the strength and other properties when partially replaced with Kunkur fines.

Experimental study design was employed. The main research method was laboratory research. Samples of concrete mixes containing varying amounts of Kunkur fines were made and subjected to the appropriate tests to determine the optimum amount. This is also Co relational research which aims to examine and describe the relationship between sand and Kunkur fines concrete using laboratory tests. Certain properties of Kunkur were also determined by laboratory tests as explained below. The study adopted the library, field and laboratory tests as the main forms of research.

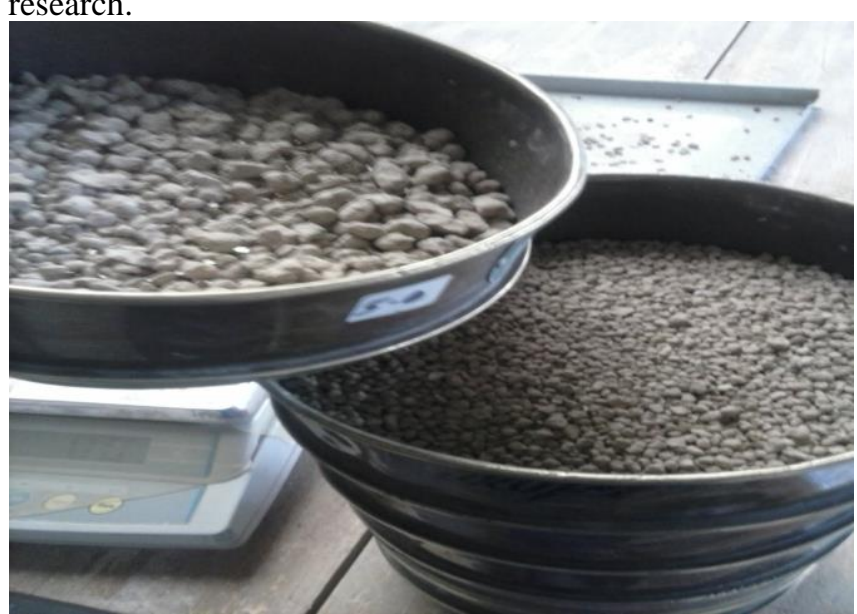

Fig 1. Sieve analysis for Aggregates Source (author 2013)

\section{RESEARCH FINDINGS}

This research work has been undertaken to assess the possibility of using kunkur waste as a partial replacement of fine aggregates in concrete. The mix ratio was 1:2:4 (Cement: Fine aggregates: Coarse aggregates) and the water was added to produce a slump of $30-60 \mathrm{~mm}$. The proportions of fine aggregates were varied (sand and kunkur) to study the behavior of concrete. The batching adopted was by weight which recommended for use in the laboratory.

\section{Slump test results}

The slump was maintained between $30-60 \mathrm{~mm}$ which gives a good workable mix. At a constant volume of water, the slump increased with increasing percentage of Kunkur and decrease of sand.

\section{Sieve Analysis}

The sieve analysis results of this study compare favorably with the BS 812 requirements where the gradation of both Kunkur fines and sand falls within the required brackets. Kunkur therefore qualifies to be classified as a fine aggregate according to BS 812 .

\section{Bulk test}

Bulking test was carried out to determine the amount of water that Kunkur and sand requires to be fully saturated. The results found that bulking of sand was $33.64 \%$ compared to Kunkur with $20.45 \%$ and this explains the reason why the slump of concrete increases with increasing amount of Kunkur fines at constant volume of water.

\section{Silt Content}

Sand recorded a silt content of 3.64\% while kunkur recorded a slightly higher value of $4.55 \%$ which is falling within the BS 812 requirements of less than 5\% and this makes kunkur to qualify for use as fine aggregates for concrete.

\section{Compressive strength test}

The research found that kunkur fines have a potential of replacing sand up to 50 percent. The $28^{\text {th }}$ day strength for 25 and $50 \%$ was close to the control mix providing the design strength of $20 \mathrm{~N} / \mathrm{mm}^{2}$. The reason why the increase in kunkur fines is recording a lower strength due to its slightly higher percentage of silt content of $4.55 \%$ compared to sand which has $3.64 \%$.

\section{Tensile and flexural strength test}

The 28 days strength was recorded for both concrete beams and cylinders using varying proportions of sand and Kunkur. The flexural strength of the concrete beams was found to be reducing with increasing amount of Kunkur fines (see table 4.13 ) with control mix recording a strength of $3.05 \mathrm{~N} / \mathrm{mm}^{2}$ reducing all the way to the plain Kunkur beam with a strength of $2.77 \mathrm{~N} / \mathrm{mm}^{2}$. This is $9.2 \%$ strength reduction in full replacement of sand and 5.9\% in partial replacement of 50\% sand with Kunkur fines.

The Tensile strength of concrete cylinders was also found to be reducing with increasing amount of Kunkur fines (see table 4.12) with control mix recording a strength of $2.21 \mathrm{~N} / \mathrm{mm}^{2}$ reducing all the way to the plain Kunkur beam with a strength of $1.73 \mathrm{~N} / \mathrm{mm}^{2}$. This is $21.7 \%$ strength reduction in full replacement of sand and $7.23 \%$ in partial replacement of $50 \%$ sand with Kunkur fines. The results of this study compare favorably with the literature review which stated that concrete is good in compressive strength but very poor in tensile strength as its evident in the results that concrete is giving very low values for the tensile and flexural strength compared to the compressive strength of the same age and the same mix under similar conditions.

Table 1. Mix Code and descriptions

\begin{tabular}{|l|l|l|}
\hline Mix code No. & Mix code & $1: 2: 4$ Mix description \\
\hline 1 & K0:S100 & Control mix with 0\% kunkur and 100 \% sand \\
\hline 2 & K25:S75 & Concrete with 25\% kunkur and 75 \% sand \\
\hline 3 & K50:S50 & Concrete with $50 \%$ kunkur and $50 \%$ sand \\
\hline 4 & K75:S25 & Concrete with 75\% kunkur and 25 \% sand \\
\hline 5 & K100:S0 & Concrete with $100 \%$ kunkur and 0 \% sand \\
\hline
\end{tabular}

Key: K> Kunkur, S>sand

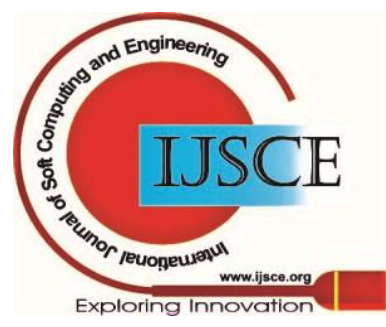


Table 2. Mix batch proportions

\begin{tabular}{|l|c|c|c|c|c|}
\hline Constituents & \multicolumn{5}{|c|}{$\begin{array}{c}\text { Mix } \\
\text { type }\end{array}$} \\
\hline Mix code no. & $\mathbf{1}$ & $\mathbf{2}$ & $\mathbf{3}$ & $\mathbf{4}$ & $\mathbf{5}$ \\
\hline Cement & 7.70 & 7.70 & 7.70 & 7.70 & 7.70 \\
\hline Sand & 13.64 & 10.23 & 6.82 & 3.41 & 0.00 \\
\hline Kunkur & 0.00 & 3.41 & 6.82 & 10.23 & 13.64 \\
\hline Coarse aggregates & 20.47 & 20.47 & 20.4 & 20.47 & 20.47 \\
\hline Water & 4.25 & 4.45 & 4.73 & 4.69 & 5.20 \\
\hline
\end{tabular}

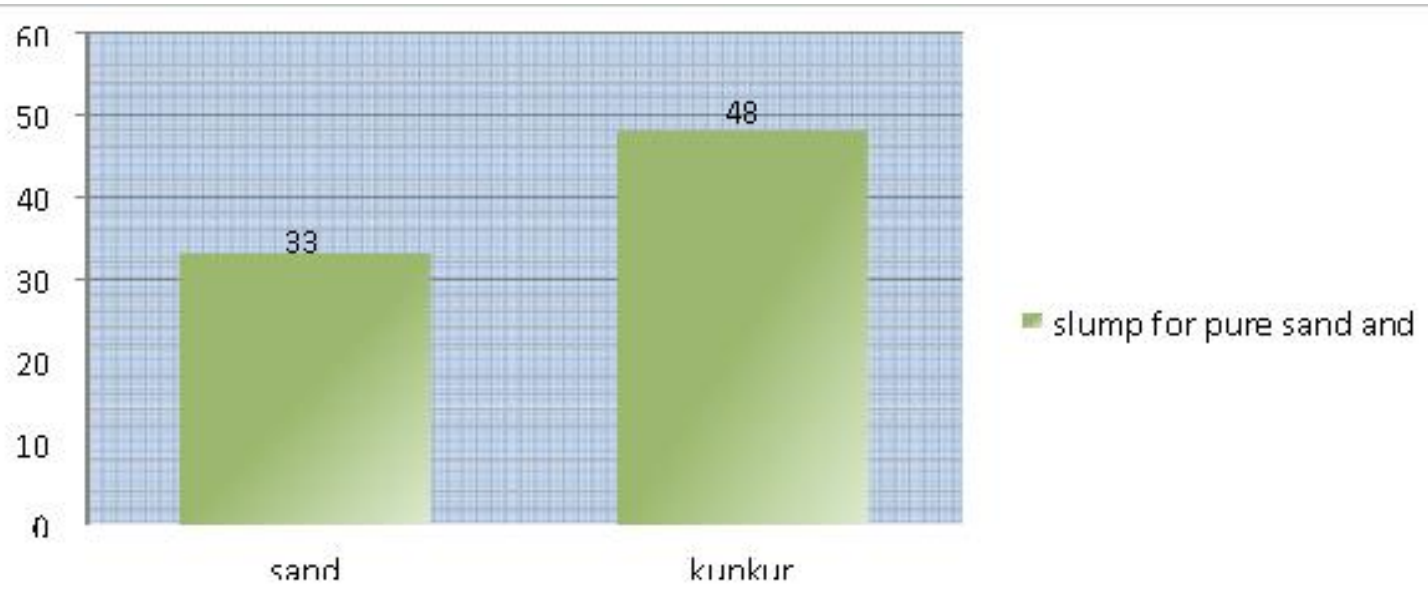

Tvoe of fine agoregates

Fig 1. Slump results for pure sand and pure kunkur. (Source author 2013)

Table 3. Slump Test Results (30-60 mm)

\begin{tabular}{|c|c|c|c|c|c|}
\hline & \multicolumn{5}{|c|}{ Mix type } \\
\hline & $\mathbf{1}$ & $\mathbf{2}$ & $\mathbf{3}$ & $\mathbf{4}$ & $\mathbf{5}$ \\
\hline $\begin{array}{c}\text { Slump Results } \\
(\mathrm{mm})\end{array}$ & 33 & 35.5 & 38 & 42 & 48 \\
\hline
\end{tabular}

Table 4. Compressive Strength test results

\begin{tabular}{|c|c|c|c|}
\hline Type of mix & $\begin{array}{l}\text { Class } \\
\left(\mathrm{N} / \mathrm{mm}^{2}\right)\end{array}$ & $\begin{array}{l}\text { Age of curing } \\
\text { (days) }\end{array}$ & $\begin{array}{l}\text { Average } \\
\text { Compressive } \\
\text { strength } \\
\left(\mathrm{N} / \mathrm{mm}^{2}\right)\end{array}$ \\
\hline \multirow{3}{*}{$\begin{array}{l}\text { Control mix (0\% } \\
\text { K: } 100 \% \mathrm{~S})\end{array}$} & \multirow{3}{*}{20} & 7 & 13.5 \\
\hline & & 14 & 17.78 \\
\hline & & 28 & 20.76 \\
\hline \multirow{3}{*}{$\begin{array}{l}\text { Blended mix (25\% } \\
\text { K: } 75 \% \text { S) }\end{array}$} & \multirow{3}{*}{20} & 7 & 12.17 \\
\hline & & 14 & 16.64 \\
\hline & & 28 & 20.17 \\
\hline \multirow{3}{*}{$\begin{array}{l}\text { Blended mix (50\% } \\
\text { K: } 50 \% \text { S) }\end{array}$} & \multirow{3}{*}{20} & 7 & 11.78 \\
\hline & & 14 & 16.53 \\
\hline & & 28 & 19.83 \\
\hline \multirow{3}{*}{$\begin{array}{l}\text { Blended mix }(75 \% \\
\text { K: 25\% S) }\end{array}$} & \multirow{3}{*}{20} & 7 & 11.26 \\
\hline & & 14 & 15.39 \\
\hline & & 28 & 17.37 \\
\hline \multirow{3}{*}{$\begin{array}{l}\text { Blended mix } \\
(100 \% \mathrm{~K}: 0 \% \mathrm{~S})\end{array}$} & \multirow{3}{*}{20} & 7 & 8.26 \\
\hline & & 14 & 12.47 \\
\hline & & 28 & 16.30 \\
\hline
\end{tabular}

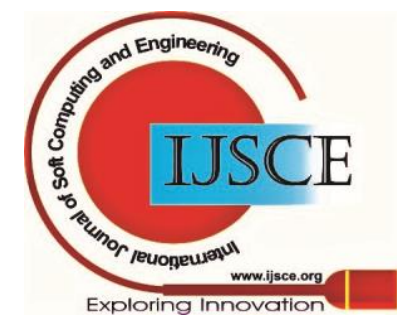


An Investigation to Replace sand with Kunkur Quarry dust as fine Aggregates in Concrete.

Table 5. Tensile Strength test results

\begin{tabular}{|l|l|l|l|}
\hline Type of Mix & $\begin{array}{l}\text { Class } \\
(\mathrm{N} / \mathrm{mm} 2)\end{array}$ & $\begin{array}{l}\text { Age of } \\
\text { curing } \\
(\text { days })\end{array}$ & $\begin{array}{l}\text { Average } \\
\text { e strength (N/mm2) }\end{array}$ \\
\hline $\begin{array}{l}\text { Control mix } \\
(0 \% \text { K: } 100 \% \text { S })\end{array}$ & 20 & 28 & 2.21 \\
\hline $\begin{array}{l}\text { Blended mix } \\
(25 \% \text { K: } 75 \% \text { S })\end{array}$ & 20 & 28 & 2.10 \\
\hline $\begin{array}{l}\text { Blended mix } \\
(50 \% \text { K: } 50 \% \text { S })\end{array}$ & 20 & 28 & 2.05 \\
\hline $\begin{array}{l}\text { Blended mix } \\
(75 \% \text { K: } 25 \% \text { S) }\end{array}$ & 20 & 28 & 1.86 \\
\hline $\begin{array}{l}\text { Blended mix } \\
(100 \% \text { K: } 0 \% \text { S) }\end{array}$ & 20 & 28 & 1.73 \\
\hline
\end{tabular}

\section{RESEARCH FINDINGS (CONTINUED)}

Kunkur fines from EAPCC quarry is a potential material in replacing sand for fine aggregates as it qualifies the tests which are required to regard a material as having sufficient structural strength and suitable for use as fine aggregate. An increase of Kunkur fines in the blend slightly reduces the strength of concrete. Up to 50\% replacement the blend gives sufficient structural strength of $20 \mathrm{~N} / \mathrm{mm}^{2}$ and above with further increase of Kunkur recording lower values than the design strength. Kunkur has low silt content which is slightly higher than that of sand by $0.91 \%$ but below the maximum required percentage by BS 812 of $5 \%$. It was also found that Kunkur requires less water than sand to be saturated and thus an increase in Kunkur content reduces the amount of water required to give a concrete mix of a certain slump. The particle size distribution falls within the BS 812 requirement brackets and this makes Kunkur a potential substituent material for sand in concrete as fine aggregates.

Following a national outcry by environment management organizations both governmental and non-governmental to preserve rivers it's seen to be strongly backed by political leaders which is posing a great threat to the future of construction industry. This therefore calls for thorough investigations on alternative materials which can potentially be used to replace sand either partially or fully to help preserve rivers which are the major source of sand. Sand harvesting is associated with drying up of rivers which causes water problems to the communities during the dry period.

The research recommends the use of Kunkur fines as it will help reduce the amount of sand harvested in the rivers annually by half and this will reduce the effect of water scarcity in the affected areas. Its use will also solve the problem of heap disposal by the EAPCC in the mines as the waste will be appropriately used in the construction industry. The disposal which is currently a major concern to the cementers may be converted to a source of income by selling the "waste" to builders.

\section{CONCLUSION}

Due to ability of Kunkur fines to partially replace river sand up to $50 \%$ it should adopted and embraced by professional practitioners in the construction industry to help reduce the high demand of sand which causes the over exploitation in the rivers leaving them exposed and un able to preserve water during hot and dry periods. If these fines are adopted in the industry then the annual demand of sand will be expected to reduce by approximately half as it replaces sand by $50 \%$. Kunkur requires lower amount of water to be saturated and this means that it absorbs less water than sand. If the two are blended then they will give a good workable mix at a constant $\mathrm{W} / \mathrm{C}$ ratio compared to when plain sand is used and this was evident in the slump tests carried out.The reducing strength trend as more Kunkur is added indicates that it contains higher deleterious materials and therefore a washed sample should be examined and check whether it can replace sand fully. The study affirms the potential of Kunkur waste at 50\% replacement of sand in concrete and thus providing a solution to the current waste disposal problems at the EAPCC Kunkur mines.

\section{ACKNOWLEDGMENT}

I would like to thank my supervisors, Dr. Gwaya Abednego, $\mathrm{PhD}$ and Professor. Diang'a Stephen, PhD, for their endless support and words of encouragement through the entire research period. I would also like to recognize efforts of the entire construction management teaching staff for continued input and motivation during the entire period, which saw the success of this research work.

\section{REFERENCES}

1. British Standard Institution, BS 1881-116:1983, "Method for Determination of Compressive Strength of Concrete Cubes," London.

2. British Standard Institution, BS1881-117:1983, "Method for Determination of Tensile Splitting Strength,” London.

3. British Standard Institution, BS1881-118:1983, "Method for Determination of Flexural Strength," London.

4. http://en.wikipedia.org/w/index.php?title=Concrete\&oldid=51988229 7(12th. Nov

5. .2012)

6. http://www.aggregain.org.uk/quality/aggregates_standards/european.h tm (1.Nov

7. .2012)

8. Hudson, B.P. (1997). Manufactured sand for Concrete. The Indian Concrete Journal

9. Kivutha, K. (2013). Effects of sand harvesting to community, Standard Digital April 23.

10. Mutua, A.N. (2013). Effects of sand harvesting to community, Standard Digital April 23.

\section{Published By:}

Blue Eyes Intelligence Engineering and Sciences Publication

(C) Copyright: All rights reserved.

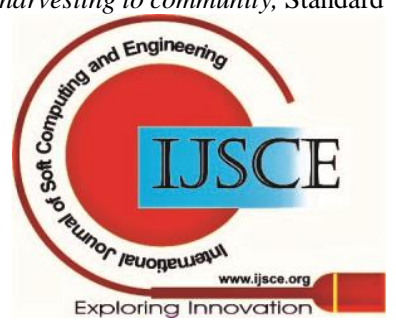


11. Munyi, M.D and Eikawa, T. (1984). Experiments in concrete technology. Nairobi, JKUAT.

12. Murdock, L.J., Brook, K.M., Dewar, J.D. (1991), Concrete Materials \& Practice,

13. 6th Edition; London Melbourne Auckland, London.

14. Neville, A.M., Brooks , J.J., (1995), Concrete Technology, star press Singapore

15. Ochola, J A. (2005). A case of partial replacement of sand with Quarry waste in concrete. Unpublished undergraduate thesis, JKUAT.

16. Puttappa N.K, Babu K.K., Radhakrishnan R. and Nambiar, E.K. (1997). Compressive Strength of Brick Masonry with Alternative Aggregate Mortar. CE and CR Journal, New Delhi.

17. Prentice, E J. (1990). Geology of construction materials. London. Chapman and hall.

18. Taylor, W.H (1977). Concrete technology and practice, fourth edition. London. Longman Group.

19. Veschre, E (2002), Concrete technology and practice. Classification of aggregates

\section{AUTHOR PROFILE}

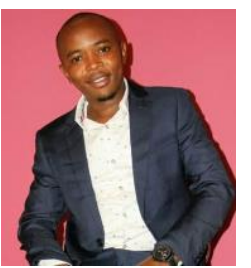

Mr. Dennis Mumo Ndolo: Bachelor of Constr. Mngt, JKUAT, Msc. Construction Project Management, JKUAT, (PhD, Ongoing JKUAT).

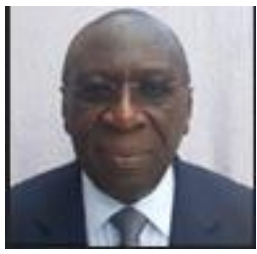

Prof. Stephen Diang'a $(\mathrm{PhD}$, Durban University). Member of BORAQS, Housing \& Urban Planning, Architecture.

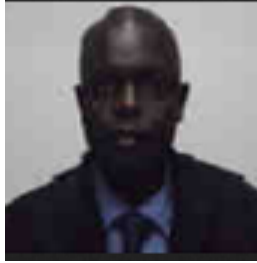

Dr. Abednego Gwaya: B.A (Bldg. Econ.), U.O.N, MSc Civil Eng. Makerere, Ph.D (Const. Eng. \& Mngt).JKUAT. Specialization: Construction Project Management, Civil Engineering construction, Contract Documentation, Project Management modeling, Project Procurement Systems and General Quantity Surveying

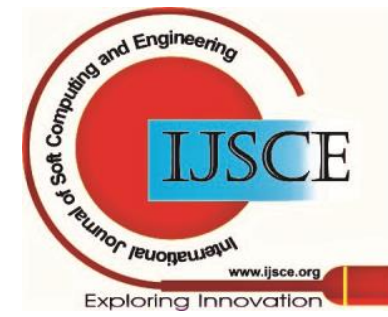

